\title{
Subglacial floods and the origin of low-relief ice-sheet lobes
}

\author{
E. M. ShoemakeR \\ Department of Mathematics and Statistics, Faculty of Sciences, Simon Fraser University, \\ Burnaby, British Columbia V5A 1S6, Canada
}

\begin{abstract}
The likely genesis of low-relief ice-sheet lobes is episodic subglacial floods which occur in the form of water sheets hundreds of kilometers wide. During the few weeks prior to termination, when the flood discharge is large, the average thickness of a water sheet beneath the Lake Michigan lobe likely exceeded $1 \mathrm{~m}$ and reached thicknesses in excess of $6 \mathrm{~m}$. The release of a part of the basal shear stress during this period produced an elongation of the lobe of tens of kilometers.
\end{abstract}

\section{INTRODUCTION}

Mathews (1974) showed that when the near margin of the Laurentide ice sheet occupied regions where the total bed relief was $60 \mathrm{~m}$ or less the ice profile was very low. Using the classical parabolic formula

$$
h=A x^{\frac{1}{2}}
$$

which corresponds to a uniform basal shear stress $\tau_{\mathrm{b}}$ on a horizontal bed (Orowan; in British Glaciological Society, 1949), Mathews determined average $A$ values near the margin from recessional moraines and lateral meltwater channel marks. Here $h$ is ice thickness and $x$ is distance from the terminus. $A$ values of $0.32,0.46,0.55$, $0.67,0.73$, and $1.0 \mathrm{~m}^{\frac{1}{2}}$ were obtained from a number of examples. These values correspond to a $\tau_{\mathrm{b}}$ range between 0.46 and $4.5 \mathrm{kPa}$, remarkably low values.

Note that Mathews was incorrect when converting $A$ values to $\tau_{\mathrm{b}}$ values. Thus, $\tau_{\mathrm{b}}$ is proportional to $A^{2}$; evidently, Mathews took $\tau_{\mathrm{b}}$ to be proportional to $A$. His calculated range of $\tau_{\mathrm{b}}$ was about $7-20 \mathrm{kPa}$ instead of $0.46-$ $4.5 \mathrm{kPa}$. The question raised by Mathews, how ice with such a low basal shear stress can move forward and build morainal ridges containing far-travelled erratics, not only remains to be answered but is more perplexing than he imagined.

Mathews (1974) also showed that ice-surface profiles traversing mountainous terrain fit $A$ values in the range $1.8-4.1 \mathrm{~m}^{\frac{1}{2}}$ with corresponding $\tau_{\mathrm{b}}$ values in the range 15 $76 \mathrm{kPa}$. He postulated that $A$ increases with increasing bed relief but offered no physics.

The question raised by Mathews will be re-examined. The possibility of the advance of low-relief ice lobes under quasi-steady-state conditions will be considered and shown to be unlikely. A model will then be developed which advocates glacier advance by discrete events. Each event is triggered by a subglacial jökulhlaup which dis- charges in the form of a water sheet rather than a subglacial channel. The ice is floated forward during each episode, after which the lobe returns to a dormant state. Conditions under which jökulhlaups assume the form of a water sheet will be established. The model is independent of whether or not the ice is cold-based near the terminus and is independent of bed properties such as the permeability of the substrate. It is necessary, however, that subglacial melting and ponding occur upstream.

\section{THE EXAMINATION OF STEADY-STATE ICE FLOW}

Models for studying the physics of ice sheets invariably assume steady-state or quasi-steady-state conditions. Thus, when examining whether or not ice with a low profile and a basal shear stress less than, say, $5 \mathrm{kPa}$ can advance, it is normal tacitly to assume quasi-steady-state conditions. This was the approach of Beget (1986) in his explanation for the advance of the low-profile Lake Michigan lobe. Beget's analysis will now be re-examined.

Beget first determined a value for the cohesive shear strength of subglacial till by measuring the slope of a tilldebris flow laid down at the terminus of the lobe. The calculated shear strength was about $8 \mathrm{kPa}$. He reasoned that this was a good measure of subglacial till strength beneath the Lake Michigan lobe. (This reasoning was questioned by Clark and Johnson (1989).) He then found that a basal shear stress of $8 \mathrm{kPa}$, or a corresponding $A$ value of $1.32 \mathrm{~m}^{\frac{1}{2}}$, agreed well with field data.

Having discounted the contribution of internal ice deformation to ice flux, Beget then did the same for substrate deformation using the following argument. If bed deformation is mainly responsible for ice flux, then the total volume of sediment transported to the terminus must be some small proportion of the total ice volume moving through the glacier system. However, estimates of terminal moraine volumes are several orders of magni- 
tude lower than Pleistocene ice "flux" (sic), so that some mechanism other than bed deformation must be primarily responsible for ice flux. I agree with the conclusion for another reason. The $\tau_{\mathrm{b}}$ values cited earlier are so low that bed deformation is unlikely for these lobes because the driving stress is less than the cohesive strength $C$ of the substrate, assuming $C$ exceeds $5 \mathrm{kPa}$. It will be shown that the driving stress of the Lake Michigan lobe was probably less than $5 \mathrm{kPa}$, so that the same conclusion applies.

Having tacitly assumed a quasi-steady-state model, Beget went on to conclude that, by elimination, basal sliding must be primarily responsible for the ice flux. I disagree with the conclusion. Alley (1989) concluded that the sliding velocity over a till bed, if such exists, must be small compared to bedrock beds. Using the small $\tau_{\mathrm{b}}$ values cited above and, for example, a Weertman sliding law (Weertman, 1957, 1964, 1971; Paterson, 1981), it is easy to show that bedrock sliding velocities are far too low to account for the estimated ice flux required to maintain an ablating ice-sheet terminus.

High sliding velocities have not been observed beneath contemporary glaciers with till beds. Boulton and Hindmarsh (1987) claimed to have observed localized basal sliding velocities about $10 \%$ of the basal ice velocity; till deformation accounted for the remaining $90 \%$. Engelhardt and others (1978) measured little or no basal slip beneath Blue Glacier. There appears to be no situation where steady-state sliding over a soft bed is both significant and dominates the contribution to basal velocity due to bed deformation.

Brown and others (1987) arrived at a different conclusion. They developed a quasi-steady-state softbed sliding model and concluded that a $500 \mathrm{~m} \mathrm{a}^{-1}$ sliding velocity over till could be developed with the Puget lobe driving stress of $40 \mathrm{kPa}$ and a basal water pressure at least $90 \%$ of the overburden pressure. Presumably, the model could be used to explain the steady-state advance of a lobe with a driving stress, say, $4 \mathrm{kPa}$ simply by increasing the basal water pressure.

I do not favor the application of this model to the present problem for several reasons. First, a steadystate model ignores the record of episodic advance and retreat of lobes (Clayton and others, 1985). Secondly, the steady-state drainage model proposed by Brown and others (1987) would probably not exist for lobes with a cold terminus for reasons to be given. Thirdly, the steady-state model requires that as $A$ decreases the basal water pressure and water-layer thickness must increase in particular ways. There is no physical reason why a restraint of this sort would be satisfied. Fourthly, evidence of deposition from water flowing in broad sheet-like layers (Brown and others, 1987) fits an episodic drainage model better than a steady-state model. Brown and others (1987) had assumed a sub-millimeter thick water layer but their field evidence suggests a much wider variation in water-layer thickness. Fifthly, dormant ice is common in valley glaciers, particularly in post-surge glaciers. Why disregard the possiblity that low-relief icesheet lobes are in a dormant state. As remarked earlier, we are conditioned to seek steady-state models. Finally, I believe that the model of Brown and others (1987) is flawed. They disregarded the fact that the substrate pore-water pressure is regulated by the channel pressure (Shoemaker and Leung, 1987). In addition, they assumed that the difference between the overburden pressure and channel pressure is "slight". A calculation of channel pressures would have disclosed that within 50$200 \mathrm{~km}$ of the terminus channel pressures are much lower than they assumed. In summary, their assumed range of pore-water pressure is inconsistent with pressures predicted by a quasi-steady-state coupled channel-substrate drainage model.

I conclude that the maintenance (much less the advance) of a low-profile ice-sheet lobe under quasi-steadystate conditions is very unlikely. This suggests that the advance of these lobes might be by discrete events and this possibility will be considered in the next section.

Before leaving the present topic, I will re-examine Beget's (1986) calculation of $A$ for the Lake Michigan lobe. In using Equation (1) to calculate an average $\tau_{\mathrm{b}}$, and neglecting isostatic adjustments, it is appropriate to assume a horizontal bed. Thus, the local Lake Michigan depression should have been neglected in his calculation. Taking a length of $400 \mathrm{~km}$ and an ice thickness $h$ of $450 \mathrm{~m}$ (instead of $630 \mathrm{~m}$ ) gives $A \simeq 0.71 \mathrm{~m}^{\frac{1}{2}}$ and an average basal shear stress $\tau_{\mathrm{b}}=2.3 \mathrm{kPa}$. With this interpretation, the Lake Michigan lobe is unlikely to have produced any bed deformation under quasi-steady-state conditions.

\section{EPISODIC ADVANCE OF AN ICE-SHEET LOBE}

There is stratigraphic evidence that a total of at least $3000 \mathrm{~km}$ of advance and retreat occurred between 12300 and $10800 \mathrm{BP}$, particularly for the Red River lobe (Clayton and others, 1985). During this time period, episodes of ice-margin advance occurred even though the ice margin was generally undergoing rapid retreat (Clayton and Moran, 1982). Clayton and others (1985) interpreted this and similar results as evidence for icesheet surges. The interpretation given here is that subglacial jökulhlaups produced periodic surge-like behaviour downstream from major subglacial lakes or regions of many smaller subglacial lakes. Estimates of icemargin advance triggered by a subglacial jökulhlaup will be given later.

\section{Subglacial water ponding}

It is necessary to assume that the ice sheet is warm-based in its interior, although it may be cold-based under thin ice near the margin. It is necessary to assume that not all the subglacial meltwater is continuously evacuated so that subglacial ponding occurs in bed depressions. The ponded water is moved downstream or evacuated by discrete subglacial floods (jökulhlaups).

The assumption of subglacial water storage and drainage by discrete events is supported by theory and field observations. I first became aware that steadystate subglacial drainage is very unlikely beneath large ice sheets when trying to extend the model of Shoemaker and Leung (1987) to drainage distances the order of 500$1000 \mathrm{~km}$ for a temperate ice sheet. Two factors (in addition to cold basal ice) oppose steady-state drainage over large drainage lengths. First, Röthlisberger channels cannot be maintained under steady-state conditions on a long wavy bed. The tendency is for flow to be cut off 
downstream from major bed depressions. The putative condition that the channel pressure cannot exceed the overburden pressure tends to be violated at bed depressions. Secondly, even on a flat bed, channel pressures approach the overburden pressure near ice divides and pressure gradients approach zero. This makes it impossible for all the meltwater to reach channels by way of ground-water flow or along the bed so that subglacial water storage takes place at least near the centre of the ice sheet.

Wright (1973) showed that the cross-sectional area of tunnel valleys is far too great to be consistent with steady-state subglacial drainage. Results of Ehlers (1981), Grube (1983) and Boyd and others (1988) support this conclusion. This is strong evidence for discrete drainage events.

Shaw (1983), Shaw and Kvill (1984), Shaw and others (in press) and Shaw (1989) interpreted features such as drumlins and water-laid sediments as resulting from episodic subglacial drainage. Brown and others (1987) reported evidence for water covering a significant part of the bed of the Puget glacial lobe where layers and lenses of sorted sediment appear in $80 \%$ of 25 outcrops examined in the Seattle area. Similar evidence of sorted sediments has been described by Noble and Wallace (1966), Easterbrook (1968), Shaw (1979), Minard (1980), Eyles and others (1982) and Booth (1984).

There is particular reason to question the existence of steady-state drainage and a permanent subglacial channel system on cold glaciers which characteristically have cold basal ice at the terminus. (Note that active ice streams such as Antarctic Ice Stream B, which may have a steady-state drainage system (Lingle and Brown, 1987), are currently warm-based (Blankenship and others, 1986).)

A. Iken (personal communication) reported that there is no obvious (permanent) outlet of subglacial water on (cold) White Glacier, Axel Heiberg Island. However, brief violent episodic drainage events have been noticed. An episodic drainage event was also noted on a cold glacier in northern Axel Heiberg Island with turbid water spouting up several meters (personal communication from A. Iken). H. Röthlisberger (personal communication) reported seeing turbid water spouting out of the snout of a (cold) glacier on Baffin Island. Glacier floods from partially cold Swiss glaciers have been recorded by Haeberli (1983). Haeberli (1981) also noted that subglacial permafrost represents a barrier to water movement. Subglacial lakes are known to exist beneath Antarctic ice (Oswald and Robin, 1973; Cudlip and McIntyre, 1987).

There is controversy surrounding the thermal regime of continental ice sheets near their margins. Some (Shaw, 1971; Moran and others, 1980) have argued for cold basal ice, whereas Hindmarsh and others (1989) supported a warm basal ice regime. Hooke (1977) and Sugden (1977) appear to have supported either hypothesis depending upon the exact environmental conditions. In my view, ice-thrust features (Moran and others, 1980) are a compelling argument in support of cold-based marginal ice. Note that the existence of cold-based marginal ice is not required for subglacial ponding.

If subglacial water-ponding occurs beneath continen- tal ice sheets, it is reasonable to deduce that discrete drainage events must occur in the form of subglacial jökulhlaups, since this form of discrete drainage event occurs commonly on contemporary glaciers. An individual jökulhlaup could result in either moving water downstream between subglacial lakes or could (and eventually would) result in water discharge from beneath the terminus. The latter could be the result of a small jökulhlaup triggering a larger one from a large downstream subglacial lake.

The Great Lakes depressions are prominent basins where subglacial ponding is likely to have occurred. Jökulhlaups issuing from any of these basins would be major floods. I will argue that jökulhlaups from these basins floated marginal ice forward and formed the sequence of low-profile lobes which bear the names of the individual lakes.

\section{Subglacial water-sheet jökulhlaups}

The present physics of jökulhlaups is essentially unchanged from the theory of Nye (1976). Although some consideration has been given to the cross-sectional shape of the subglacial conduits which drain subglacial lakes (Nye, 1976; Spring and Hutter, 1981; Clarke, 1982), all treatments of subglacial jökulhlaups assume a Röthlisberger channel as opposed to a broad water sheet. Aside from the difference in the cross-sectional geometry, the essential difference between a channel and water sheet is that the former can operate at pressures less than the overburden pressure, whereas a water sheet derives from and results in glacial lift-off.

I will present a sufficient condition for a subglacial jökulhlaup to take the form of a water sheet, noting that water sheets may result under circumstances where this condition is not met. I will not address the question of how the breadth of a water sheet is determined. Note that water-sheet jökulhlaups might be meters thick. Water sheets of this thickness lie outside the bounds of sub-millimeter thick water films (Hallet, 1979; Brown and others, 1987) and water sheets as considered by Weertman $(1957,1966,1969,1972)$ or Walder (1982).

Just downstream from the subglacial lake, the jökulhlaup must discharge through a subglacial channel or channels. (The cross-sectional shape of the channels is unimportant.) The reason is that as the lake level drops the necessary condition for the existence of a water sheet, pressure sufficient to produce glacier lift-off, fails to be satisfied at the lake outlet. Thus, once the lake level falls, the jökulhlaup cannot discharge as a water sheet at the lake outlet.

If the ice surface is concave downstream from this initial channel segment, glacial lift-off will occur near to and downstream from the concave region. The reasoning is simple. As shown by Nye (1976), the discharge in the channel is determined by the average ice-surface gradient $\bar{\alpha}$ over the channel segment. If the ice-surface gradient $\alpha$ downstream from the initial channel segment is less than $\bar{\alpha}$, the assumption that the channel continues downstream is untenable because the reduction in the pressure gradient renders the downstream channel segment incapable of carrying the discharge. Glacial lift-off occurs downstream from the concavity (and may continue upstream); a water sheet is created. (Note that 
further downstream, where $\alpha$ increases, channel flow may again be possible.)

There are at least two pertinent circumstances where there are regional changes in $\alpha$. The first results from changes in the driving stress. A bedrock bed in mountainous terrain can be expected to support more driving stress than a low effective-pressure bed on flat terrain. The second situation occurs downstream from a large subglacial lake. Shoemaker (in press) showed that in this circumstance the deviatoric stresses in the ice cause the ice-surface gradient to increase by at least an order of magnitude in a transition region of length the order of kilometers. Therefore, just downstream from this high surface-gradient transition region the ice surface will be concave.

It follows that there are at least two situations where jökulhlaups will assume the form of a water sheet. The first is where subglacial water ponding takes place in a mountainous region and is released over a lowland region. The second situation occurs downstream from large subglacial water bodies such as the Great Lakes. A watersheet jökulhlaup could also be expected to develop where a subglacial channel jökulhlaup encounters the water gap beneath an ice shelf over a proglacial lake.

The discharge history of a water-sheet jökulhlaup is determined by the discharge in the channel segment just downstream from the lake. The thickness of the water sheet is then determined by this channel discharge, water-sheet width and ice-surface gradient. A simplified analysis of the determination of water-sheet thickness is given in the Appendix and that model will be applied to the Lake Michigan lobe, where the water-sheet width is taken to be equal to the lobe width.

It is emphasized that the water-sheet thickness computed from the Appendix is an average over the width of the water sheet. This is important in considering the effect of a water sheet in the reduction of basal drag. A water sheet with an average thickness of centimeters should cause little reduction in the average basal shear stress because the ice will still be grounded on a large fraction of its bed. A water sheet of average thickness $1 \mathrm{~m}$ or greater will be assumed to reduce greatly the basal shear stress over a region of flat topography such as northern Illinois. Note that, at any particular section transverse to the flow direction, we may assume that the ice is grounded at any bed obstacle elevated over 11 times the average thickness of the water sheet at this section.

Water-sheet thicknesses (gap widths) are shown in Table 1 for a $350 \mathrm{~km}$ wide water sheet, the approximate width of the Lake Michigan lobe. The $\alpha$ values correspond to Equation (1) with $A=0.7 \mathrm{~m}^{\frac{1}{2}}$. The value $\alpha=5.8 \times 10^{-4}$ occurs $360 \mathrm{~km}$ from the terminus; the value $\alpha=2.2 \times 10^{-3}$ occurs $25 \mathrm{~km}$ from the terminus. The value $V=2.5 \times 10^{12} \mathrm{~m}^{3}$ is an estimate of the water released from the Lake Michigan basin by a jökulhlaup. (Note that ice should have been grounded over the northern part of the Lake Michigan basin.) The higher value, $V=10^{13} \mathrm{~m}^{3}$, assumes that water stored in the Lake Superior basin participates in and triggers the Lake Michigan jökulhlaup. $\Delta t_{0.1,1}$ is the elapsed time during which the average water-sheet thickness is between 0.1 and $1 \mathrm{~m}$. It is clear that $\Delta t_{0,1,1}$ increases rapidly with a decrease in $\bar{\alpha} / \alpha$, reflecting the fact that the lake drains
Table 1. Elapsed times between various gap-width limits and maximum gap width as function of $\bar{\alpha} / \alpha$

\begin{tabular}{|c|c|c|c|c|c|c|c|}
\hline \multirow{2}{*}{$\begin{array}{c}V \\
\mathrm{~m}^{3}\end{array}$} & \multirow{2}{*}{\multicolumn{2}{|c|}{$\alpha$}} & \multicolumn{2}{|c|}{$\bar{\alpha} / \alpha \Delta t_{0.1,1}$} & \multirow{2}{*}{$\begin{array}{r}\Delta t_{1,6} \\
\mathrm{~d}\end{array}$} & \multirow{2}{*}{$\begin{array}{r}\Delta t_{>6} \\
\quad \mathrm{~d}\end{array}$} & \multirow{2}{*}{$\begin{array}{l}a_{\mathrm{m}} \\
\mathrm{m}\end{array}$} \\
\hline & & & & d & & & \\
\hline \multirow{6}{*}{$2.5 \times 10^{12}$} & 5.8 & $\times 10^{-4}$ & 2 & 400 & 64 & - & 2 \\
\hline & 5.8 & $\times 10^{-4}$ & 4 & 155 & 42 & - & 4.4 \\
\hline & 5.8 & $\times 10^{-4}$ & 8 & 60 & 20 & 3.0 & 9.3 \\
\hline & 2.2 & $\times 10^{-3}$ & 2 & 340 & 25 & - & 1.3 \\
\hline & 2.2 & $\times 10^{-3}$ & 4 & 130 & 29 & - & 2.9 \\
\hline & 2.2 & $\times 10^{-3}$ & 8 & 50 & 17 & $<1$ & 6.3 \\
\hline \multirow{6}{*}{$10^{13}$} & 5.8 & $\times 10^{-4}$ & 2 & 400 & 130 & 1.2 & 6.1 \\
\hline & 5.8 & $\times 10^{-4}$ & 4 & 155 & 51 & 13 & 13 \\
\hline & 5.8 & $\times 10^{-4}$ & 8 & 60 & 20 & 8.4 & 28 \\
\hline & 2.2 & $\times 10^{-3}$ & 2 & 340 & 94 & - & 4.1 \\
\hline & 2.2 & $\times 10^{-3}$ & 4 & 130 & 43 & 5.8 & 8.8 \\
\hline & 2.2 & $\times 10^{-3}$ & 8 & 50 & 17 & 5.7 & 19 \\
\hline
\end{tabular}

$V$ is total discharge. $\bar{\alpha}$ is the ice-surface gradient computed from Equation (1), $\alpha$ is the ice-surface gradient over the channel at the lake exit. $\Delta t_{0.1,1}$ is the elapsed time while the average gap width increases from 0.1 to $1 \mathrm{~m}, \Delta t_{1,6}$ is the elapsed time for a gap width between 1 and $6 \mathrm{~m}, \Delta t_{>6}$ is the elapsed time for a gap width greater than $6 \mathrm{~m}$, and $a_{\mathrm{m}}$ is the maximum value of the average gap width.

more slowly as $\bar{\alpha}$ is decreased, with $\alpha$ fixed. However, corresponding to $V=2.5 \times 10^{12} \mathrm{~m}^{3}$, the total time during which the gap width exceeds $1 \mathrm{~m}$ does not depend sensitively upon $\bar{\alpha} / \alpha$.

\section{Ice-lobe extension during jökulhlaup}

Some critical parameters which affect the mechanics of water-sheet jökulhlaups, particularly the ratio $\bar{\alpha} / \alpha$ (see Table 1), may never be well known. Nevertheless, we may assemble a reasonable understanding of the qualitative characteristics of large water-sheet jökulhlaups based upon Table 1. 1. For a $350 \mathrm{~km}$ wide water sheet, a total discharge between $2.5 \times 10^{12}$ and $10^{13} \mathrm{~m}^{3}$ and a very low-profile ice-sheet lobe $\left(A \simeq 0.7 \mathrm{~m}^{\frac{1}{2}}\right)$, the average gap width between ice and bed could exceed $1.0 \mathrm{~m}$ for weeks and ice could be entirely ungrounded for days. For a bed with a total relief less than $60 \mathrm{~m}$, we will assume complete ungrounding if the average gap width is $\sim 6 \mathrm{~m}$. 2. The gap width decreases downstream because of an increase in $\alpha$ but the effect is not pronounced except possibly very near the terminus where $\alpha$ can become large. 3 . The average basal shear stress will be significantly reduced by the water sheet and large ice-sheet extension rates can result. Estimates of the total ice-sheet lobe extension will now be made.

Beneath a water sheet, the effective pressure is zero at the top of the (soft) bed. It is reasonable to assume, in accordance with the Coulomb soil model, that the basal shear stress $\tau_{\mathrm{b}}$ is at the cohesion strength $C$ of the soil wherever the ice is grounded. Where the ice is 
ungrounded, the basal shear stress vanishes. A value of $C=8 \mathrm{kPa}$ (Beget, 1986) will be taken for $C$. Recall that I calculated a driving stress of $\sim 2.3 \mathrm{kPa}$ for the Lake Michigan lobe.

Let $i_{\mathrm{g}}$ be the fraction of ice which is grounded. $i_{\mathrm{g}}$ varies regionally but for the present development spatially averaged values of $i_{\mathrm{g}}$ will be used. From previous assumptions and values assumed for $C$ and $\tau_{\mathrm{b}}$, it is seen that as $i_{\mathrm{g}}$ decreases below 0.28 the driving stress cannot be totally equilibrated by the basal shear stress. It is clear that, as the jökulhlaup discharge increases, the average gap width increases and $i_{\mathrm{g}}$ decreases. Unfortunately, it is not possible to calculate $i_{\mathrm{g}}$ as a function of gap width for a realistic bed.

Using the Lake Michigan lobe as an example, we proceed under the assumption that average gap widths less than $1 \mathrm{~m}$ contribute little to total lobe extension. Furthermore, an average gap width greater than $6 \mathrm{~m}$ will result in complete ungrounding of the lobe except at the sides. Because of the relative times involved, shown in Table 1, the major contribution to lobe extension may occur during the partial ungrounding phase when the average gap width is $1-6 \mathrm{~m}$. To estimate the total lobe extension, it is adequate for our purposes to calculate lobe-extension rates under conditions of partial and total ungrounding and then use these results along with Table 1.

Assume that the lobe is symmetric about an axial center line $x$ (Fig. 1) and consider the extension rate along this center line. Neglect any resistance encountered at the terminus as it advances. Thus, it is assumed that the terminus does not encounter a prominent frontal moraine.

Consideration of the equilibrium of an element on the center line (Fig. 1) leads to the equation

$$
\frac{\mathrm{d}}{\mathrm{d} x}\left(\delta \sigma_{x} h\right)=\delta \tau_{\mathrm{b}}-h \partial \tau_{x y}(0) / \partial y
$$

where $\delta \sigma_{x}$ is the increase in the longitudinal (tensile) stress in the ice, and $\delta \tau_{\mathrm{b}}$ is the decrease in the basal shear stress existing at any time during the jökulhlaup. $\tau_{x y}$ is the shear stress due to drag on the sides of the parallel-sided ice lobe.

The usual assumption pertaining to ice shelves confined to parallel-sided bays is that the shear stress $\tau_{x y}$ in the floating ice has the distribution

$$
\tau_{x y}=\tau y / \ell
$$

where $\tau$ is the magnitude of the shear stress on the sides of the ice shelf (Thomas, 1973). If this assumption is invoked, Equation (2) becomes

$$
\frac{\mathrm{d}}{\mathrm{d} x}\left(\delta \sigma_{x} h\right)=\delta \tau_{\mathrm{b}}-h \tau / \ell .
$$

In the case of ice shelves, the magnitude of $\tau$ is usually taken to be $50-100 \mathrm{kPa}$ (Thomas, 1973). In the present case, $\tau$ could be larger if the sides of the floating ice lobe are entirely bounded by grounded ice, particularly if the bed of the bounding ice is capable of transmitting a large increase in shear stress. Of course, if the floating ice, or

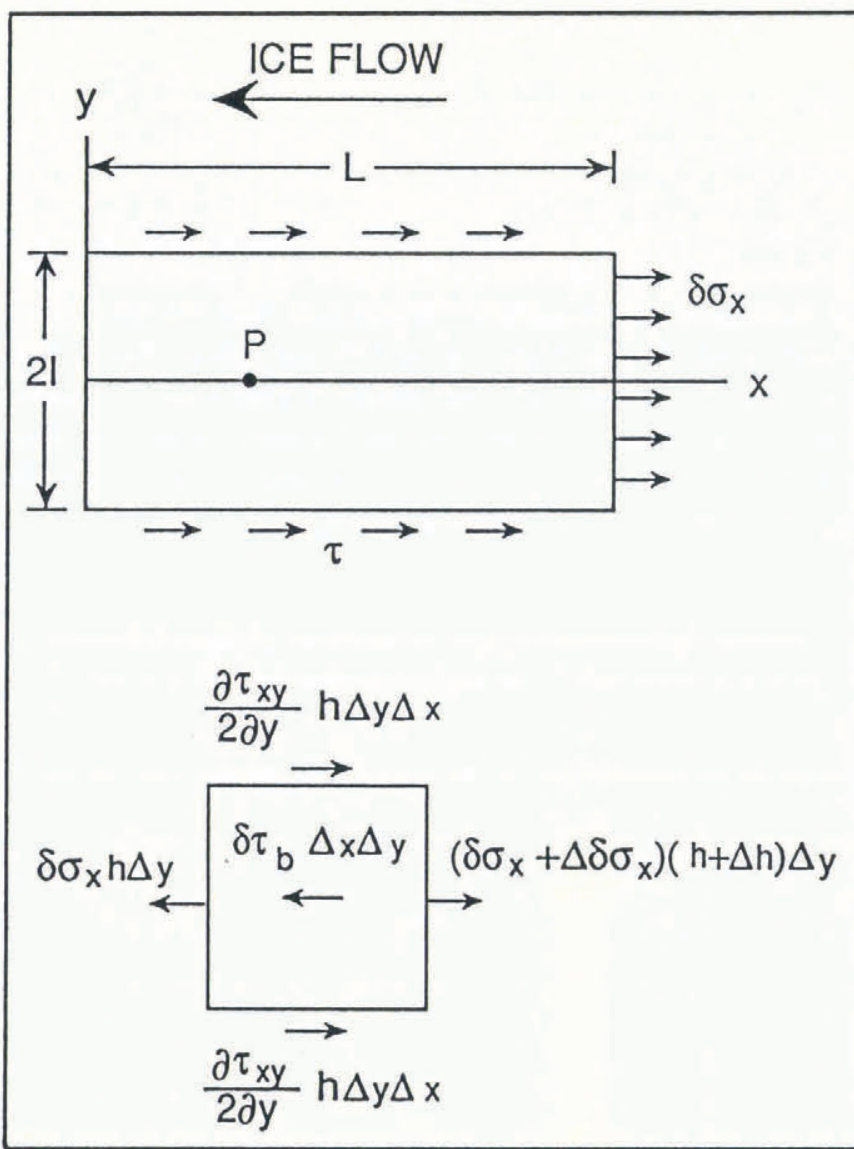

Fig. 1. Stress condition on an element of depth $h$ at arbitrary point $P$ on the center line of an idealized rectangular lobe. Terminus at $x=0$ is unrestrained.

a part thereof, is not bounded by ice, $\tau$ will be small or zero.

Note that there is an alternative view to Equation (3). Frolich and Doake (1988) showed that the term $\partial \tau_{x y} / \partial y$ could be taken to be zero near the center of Rutford Ice Stream, Antarctica. In this case, the term involving $\tau$ is absent in Equation (4).

When Equation (4) is integrated and the condition $\delta \sigma_{x}(0) h(0)$ is applied, the result is

$$
\delta \sigma_{x}=\delta \tau_{\mathrm{b}}(x)^{\frac{1}{2}} / A-2 \tau x / 3 \ell .
$$

Determination of the deviatoric stresses and substitution into the Glen $n=3$ flow law (Paterson, 1981, p. 31)

$$
\dot{\epsilon}_{x}=B \tau_{\mathrm{e}}{ }^{2} s_{x}
$$

where $B$ is the flow-law parameter, $\tau_{\mathrm{e}}$ is the effective shear stress and $s_{x}=2 \delta \sigma_{x} / 3$ the $x$ component of the deviatoric normal stress, results in

$$
\begin{aligned}
& \dot{\epsilon}_{x}=\frac{2}{27} B \\
& \cdot\left[\frac{\delta \tau_{\mathrm{b}}^{3} x^{3 / 2}}{A^{3}}-\frac{2}{3} \frac{\delta \tau_{\mathrm{b}}^{2} \tau_{x}^{2}}{A^{2} \ell}+\frac{4}{9} \frac{\delta \tau_{\mathrm{b}}}{A} \frac{\tau^{2}}{\ell^{2}} x^{5 / 2}-\frac{8}{27} \frac{\tau^{3}}{\ell^{3}} x^{3}\right] .
\end{aligned}
$$

The displacement rate $\dot{u}(0)$ of the terminus on the center 
line may then be found from

$$
\dot{u}(0)=\int_{0}^{L} \dot{\epsilon}_{x} \mathrm{~d} x .
$$

Table 2 gives the extension rate of the terminus, $\dot{u}(0)$, for various values of $\delta \tau_{\mathrm{b}}$ and $\tau$. $\delta \tau_{\mathrm{b}}=2.2 \mathrm{kPa}$ corresponds to complete ungrounding. Assuming that $\delta \tau_{\mathrm{b}}$ becomes positive as the average gap width increases above $1 \mathrm{~m}$ and that total ungrounding occurs if this value is above $6 \mathrm{~m}$, a reasonable conclusion from Tables 1 and 2 is that a total lobe extension of tens of kilometers could result from the action of a large jökulhlaup.

Table 2. Extension rates $\dot{u}(0)$ of terminus of ungrounded and partially ungrounded low-profile ice-sheet lobe, $A=0.7 \mathrm{~m}^{1 / 2}$

\begin{tabular}{crc}
\hline$\delta \mathrm{t}_{\mathrm{b}}$ & \multicolumn{1}{c}{$\tau$} & $\dot{u}(0)$ \\
& $\mathrm{kPa}$ & $\mathrm{km} \mathrm{d}^{-1}$ \\
\hline $\mathrm{kPa}$ & 0 & 4.3 \\
& 100 & 4.0 \\
2.2 & 500 & 3.4 \\
2.2 & 0 & 2.8 \\
2.2 & 100 & 2.6 \\
1.65 & 500 & 2.1 \\
1.65 & 0 & 1.5 \\
1.65 & 100 & 1.4 \\
1.1 & 500 & 1.1 \\
1.1 & 0 & 0.53 \\
1.1 & 100 & 0.48 \\
0.55 & 500 & 0.33 \\
0.55 & & \\
0.55 & & \\
& & \\
\hline
\end{tabular}

$\Delta \tau_{\mathrm{b}}=2.2 \mathrm{kPa}$ corresponds to complete ungrounding. $\Delta \tau_{\mathrm{b}}=0.55 \mathrm{kPa}$ corresponds to a one-quarter decrease in basal shear stress during a jökulhlaup.

\section{CONCLUSION}

The maintenance and even the advance of low-profile icesheet lobes can be explained as resulting from rapid extension during subglacial water-sheet jökulhlaups. The alternative, that such lobes are maintained or advance under quasi-steady-state conditions, should be rejected.

The existence of a low-profile lobe appears to depend upon the existence of a bed with low total relief. For a bed with high relief, a water-sheet jökulhlaup (unless it was enormous) would produce little reduction in average basal shear stress.

Jökulhlaups are expected to assume the form of water sheets downstream from large lakes because of the existence of a concave ice surface. The question of what determines the width of water sheets has not been considered.

It is possible that the mass balance of ice sheets is affected more by episodic events than by quasi-steadystate flow. This possibility should be considered when modeling the disintegration of an ice sheet.

It is easily shown that the elongation effect on icesheet lobes increases as the $A$ value in Equation (1) increases. Repeated jökulhlaups tend to reduce $A$ values.

The assumption of no frontal resistance to lobe advance would be invalid when the lobe encounters a large frontal moraine. This may be one reason why lobes appear to have repeatedly advanced to roughly the same position.

\section{REFERENCES}

Alley, R.B. 1989. Water-pressure coupling of sliding and bed deformation: II. Velocity-depth profiles. J. Glaciol., 35(119), 119-129.

Beget, J.F. 1986. Modeling the influence of till rheology on the flow and profile of the Lake Michigan lobe, southern Laurentide ice sheet, U.S.A. J. Glaciol., 32(11), 235-241.

Blankenship, D. D., C. R. Bentley, S. T. Rooney and R. B. Alley. 1986. Seismic measurements reveal a saturated porous layer beneath an active Antarctic ice stream. Nature, 322(6074), 54-57.

Booth, D. B. 1984. Glacier dynamics and the development of glaciated landforms in the eastern Puget lowland. (Ph.D. dissertation, University of Washington.)

Boulton, G. S. and R. C. A. Hindmarsh. 1987. Sediment deformation beneath glaciers: rheology and geological consequences. J. Geophys. Res., 92(B9), 9059-9082.

Boyd, R., D. B. Scott and M. Douma. 1988. Glacial tunnel valleys and Quaternary history of the outer Scotian shelf. Nature, 333 (6168), 61-74.

British Glaciological Society. 1949. Joint meeting of the British Glaciological Society, the British Rheologists' Club and the Institute of Metals. J. Glaciol., 1(5), 231-240.

Brown, N.E., B. Hallet and D. B. Booth. 1987. Rapid soft bed sliding of the Puget glacial lobe. J. Geophys. Res., 92(B9), 8985-8997.

Clark, P.U. and W.H. Johnson. 1989. Correspondence. Modeling the influence of till rheology on the flow and profile of the Lake Michigan lobe, southern Laurentide ice sheet, U.S.A.: discussion. J. Glaciol., 35(120), 284-286.

Clarke, G. K. C. 1982. Glacier outburst floods from "Hazard Lake", Yukon Territory, and the problem of flood magnitude prediction. J. Glaciol., 28(98), 3-21.

Clayton, L. and S.R. Moran. 1982. Chronology of late Wisconsinan glaciation in middle North America. Quat. Sci. Rev., 1(1), 55-82.

Clayton, L., J. T. Teller and J. W. Attig. 1985. Surging of the southwestern part of the Laurentide ice sheet. Boreas, 14(3), 235-241.

Cudlip, W. and N.F. McIntyre. 1987. Seasat altimeter observations of an Antarctic "lake". Ann. Glaciol., 9, 55-59.

Easterbrook, D. J. 1968. Pleistocene stratigraphy of Island County. Vol. I. Washington Department of Water Resources. Supply Bulletin 25.

Ehlers, J. 1981. Some aspects of glacial erosion and 
deposition in north Germany. Ann. Glaciol., 2, 143146.

Engelhardt, H. F., W.D. Harrison and B. Kamb. 1978. Basal sliding and conditions at the glacier bed as revealed by bore-hole photography. J. Glaciol., 20(84), 469-508.

Eyles, N., J. A. Sladen and S. Gilroy. 1982. A depositional model for stratigraphic complexes and facies superimposition in lodgement tills. Boreas, 11(4), 317-333.

Frolich, R. M. and C.S.M. Doake. 1988. Relative importance of lateral and vertical shear on Rutford Ice Stream, Antarctica. Ann. Glaciol., 11, 19-22.

Grube, F. 1983. Tunnel valleys. In Ehlers, J., ed. Glacial deposits in north-west Europe. Rotterdam, Balkema, 257-258.

Haeberli, W. 1981. Correspondence. Ice motion on deformable sediments. J. Glaciol., 27(96), 365.

Haeberli, W. 1983. Frequency and characteristics of glacier floods in the Swiss Alps. Ann. Glaciol., 4, 85-90.

Hallet, B. 1979. Subglacial regelation water film. J. Glaciol., 23(89), 321-334.

Hindmarsh, R. C. A., G. S. Boulton and K. Hutter. 1989. Modes of operation of thermo-mechanically coupled ice sheets. Ann. Glaciol., 12, 57-69.

Hooke, R. LeB. 1977. Basal temperatures in polar ice sheets: a qualitative review. Quat. Res., 7(1), 1-13.

Lingle, C. S. and T. J. Brown. 1987. A subglacial aquifer bed model and water pressure dependent basal sliding relationship for a West Antarctic ice stream. In Van der Veen, C. J. and J. Oerlemans, eds. Dynam$i c s$ of the West Antarctic ice sheet. Proceedings of a Workshop held in Utrecht, May 6-8, 1985. Dordrecht, etc., D. Reidel Publishing Co., 249-285.

Mathews, W. H. 1974. Surface profiles of the Laurentide ice sheet in its marginal areas. J. Glaciol., 13(67), 37-43.

Minard, J. P. 1980. Geology of the Maltby Quadrangle, Washington, scale 1:24,000. Open File Map 802013. Reston, VA, U.S. Geological Survey.

Moran, S. R., L. Clayton, R. LeB Hooke, M. M. Fenton and L.D. Andriashek. 1980. Glacier-bed landforms of the prairie region of North America. J. Glaciol., 25(93), 457-476.

Noble, J.B. and E.F. Wallace. 1966. Geology and groundwater resources of Thurston County. Washington Department of Water Resources. Water Supply Bulletin 10.

Nye, J.F. 1976. Water flow in glaciers: jökulhlaups, tunnels and veins. J. Glaciol., 17(76), 181-207.

Oswald, G. K. A. and G. de Q. Robin. 1973. Lakes beneath the Antarctic ice sheet. Nature, 245(5423), 251-254.

Paterson, W.S. B. 1981. The physics of glacier.s. Second edition. Oxford, etc., Pergamon Press.

Shaw, J. 1971. Mechanism of till deposition related to thermal conditions in a Pleistocene glacier. $J$. Glaciol., 10(60), 363-373.

Shaw, J. 1979. Genesis of the Sveg tills and Rogen moraine of central Sweden: a model of basal melt out. Boreas, 8, 409-426.
Shaw, J. 1983. Drumlin formation related to inverted melt-water erosional marks. J. Glaciol., 29(103), 461-479.

Shaw, J. 1989. Drumlins, subglacial meltwater floods and ocean responses. Geology, 17(9), 853-856.

Shaw, J. and D. Kvill. 1984. A glaciofluvial origin for drumlins of the Livingstone Lake area, Saskatchewan. Can. J. Earth Sci., 21(12), 1442-1459.

Shaw, J., D. Kvill, and B. Rains. In press. Drumlins and catastrophic subglacial floods. Sediment. Geol.

Shoemaker, E. M. In press. The ice topography over subglacial lakes. Cold Reg. Sci. Technol.

Shoemaker, E. M. and H. K. N. Leung. 1987. Subglacial drainage for an ice sheet resting upon a layered deformable bed. J. Geophys. Res., 92(B6), 4935-4946.

Spring, U. and K. Hutter. 1981. Numerical studies of jökulhlaups. Cold Reg. Sci. Technol., 4(3), 227-244.

Sugden, D.E. 1977. Reconstruction of the morphology, dynamics, and thermal characteristics of the Laurentide ice sheet at its maximum. Arct. Alp. Res., 9(1), 21-47.

Thomas, R.H. 1973. The creep of ice shelves: theory. J. Glaciol., 12(64), 45-53.

Walder, J.S. 1982. Stability of sheet flow of water beneath temperate glaciers and implications for glacier surging. J. Glaciol., 28(99), 273-293.

Weertman, J. 1957. On the sliding of glaciers. $J$. Glaciol., 3(21), 33-38.

Weertman, J. 1964. The theory of glacier sliding. J. Glaciol., 5(39), 287-303.

Weertman, J. 1966. Effect of a basal water layer on the dimensions of ice sheets. J. Glaciol., 6(44), 191-207.

Weertman, J. 1969. Water lubrication mechanism of glacier surges. Can. J. Earth Sci., 6(4, Pt. 2), 929942.

Weertman, J. 1971. In defense of a simple model of glacier sliding. J. Geophys. Res., 76(26), 6485-6487.

Weertman, J. 1972. General theory of water flow at the base of a glacier or ice sheet. Rev. Geophys. Space Phys., 10(1), 287-333.

Wright, H.E. 1973. Tunnel valleys, glacial surges and subglacial hydrology of the Superior lobe, Minnesota. Geol. Soc. Am. Mem. 136, 251-276.

The accuracy of references in the text and in this list is the responsibility of the author, to whom queries should be addressed.

\section{APPENDIX}

\section{JÖKULHLAUP-DISCHARGE PROPERTIES AND WATER-SHEET THICKNESS}

Nye (1976) showed that for a jökulhlaup discharging through a subglacial channel the discharge $Q$ is uniform along the length of the channel. This need not be the case for water-sheet flow because of the large (spatially dependent) storage capacity of the water sheet. However, for qualitative purposes, it is reasonable to assume the $Q$ is uniform along the length of the water sheet. It will also be assumed that length $L$ and width $2 \ell$ are 
fixed. (Note that length $L$ will actually increase during the jökulhlaup.)

Consider the following one-dimensional problem. At the outlet to the subglacial lake the jökulhlaup discharges through a single subglacial channel. The ice-surface gradient above the channel is taken to be a constant $\bar{\alpha}$. A water sheet exists downstream from the channel segment. The ice surface over the water sheet is assumed to be parabolic according to Equation (1). Thus, the ice-surface gradient is

$$
\alpha=A x^{-\frac{1}{2}} / 2
$$

except possibly very near the terminus. I employ equations of Nye (1976) and denote these by the prefix N.

The characteristics of the channel flow are first developed from (N32) and (N31), respectively giving

$$
\begin{gathered}
Q=\left(-4 / K_{2} t\right)^{4} \\
K_{2}=\frac{4 g}{3 w_{\mathrm{i}} L N^{3 / 8}}\left(w_{\mathrm{i}} \bar{\alpha}\right)^{11 / 8} .
\end{gathered}
$$

Here, time $t=0$ corresponds to infinite discharge $Q$. Thus the jökulhlaup terminates at a negative time. $L$ is the specific latent heat of fusion of ice and $w_{\mathrm{i}}$ is the unit weight of ice. I take a value of $N=700 \mathrm{~m}^{-8 / 3} \mathrm{~kg}$ which is very close to the value used by Nye (1976) for the Grimsvötn jökulhlaup.

Equation (A.2) is integrated to give the total discharge $V$. Solving the resulting equation for $t^{*}$, the time corresponding to the total discharge $V$ gives

$$
t^{*}=-\left(4 / K_{2}\right)^{4 / 3}(1 / 3 V)^{1 / 3} \text {. }
$$

The corresponding maximum discharge $Q_{\mathrm{M}}$ from Equat- ion (A.1) is

$$
Q_{\mathrm{M}}=\left(-4 / K_{2} t^{*}\right)^{4} .
$$

Given the total discharge $V$, which may be estimated by considering the particular basin involved, such as Lake Michigan, the termination time $t^{*}$ of the jökulhlaup can be estimated from Equation (A.4) and the discharge history from Equations (A.2) and (A.5).

Two cautionary points are emphasized. First, $Q$ is proportional to $(\bar{\alpha})^{-11 / 2}$ and $t^{*}$ is proportional to $(\bar{\alpha})^{11 / 6}$. Because parameter $\bar{\alpha}$ is subject to uncertainty, the discharge history of the jökulhlaup is subject to even greater uncertainty. Secondly, the concept of duration time of the jökulhlaup is not meaningful because this depends upon the initial jökulhlaup discharge which is unknown. For example, the initial jökulhlaup discharge theoretically could approach zero, in which case the duration time approaches infinity. In the present application, we are only interested in the duration time during which the average glacial lift-off is at least $1 \mathrm{~m}$. This latter duration time will be determined by considering the flow equation of the water sheet.

Assume turbulent flow and a water sheet of rectangular cross-section with water-sheet thickness (gap width) $a$ and sheet width $2 \ell$. Use equation (N12) written as

$$
w_{\mathrm{i}} \alpha=N_{\mathrm{s}} Q^{2} / S^{8 / 3}
$$

where $N_{\mathrm{s}}=\left(S / R^{2}\right)^{2 / 3} w_{\mathrm{w}} n^{2} . S=2 \ell a$ is the crosssectional area, $R=a / 3$ is the hydraulic radius and $w_{\mathrm{w}}$ is the unit weight of water. A value for the Manning roughness $n=0.035$ (S.I.) corresponding to a very rough wall will be used. With $Q$ given by Equation (A.2), and for given $\ell$ and $\alpha$, Equation (A.6) may be solved for $a$ giving

$$
a=Q^{3 / 5} 5.47 \alpha^{3 / 10}(2 \ell)^{3 / 5} \text {. }
$$

